\title{
PERANAN KETERLIBATAN DALAM JEJARING SOSIAL DAN KEHATI-HATIAN DALAM MEMBENTUK PERSISTENSI PELANGGAN ONLINE YANG PERNAH MENGALAMI PENIPUAN
}

\author{
Aneke Dewi Rahayu \\ Fakultas Psikologi Universitas Teknologi Yogyakarta
}

\begin{abstract}
Internet network had been developed over the years and its utilization has also increased and extended to various fields including midwives venturing into online business. Online transaction can be performed through digital media and do not require a direct meeting between the seller and the buyer. Online purchase is called with an e-commerce where the system continues to experience growth. As this growth there is a lot of cheating and fraud. The number does not decrease the negative impact of buying interest someone through e-commerce. There are two variables are taken into consideration, namely the emergence of persistent involvement in social networks and the prudence of a person due to lack of trust after fraud. The purpose of this study was to determine the effect of a person's involvement in social networks and caution against the persistence of online customers who have experienced fraud. Methods of analysis using path analysis with AMOS program. The results of this study are involved in social networking direct or indirect effect on the variable persistence through prudential variable.
\end{abstract}

Keywords: involvement in social networking, prudence, persistence, e-commerce, customers who have experience fooled

\begin{abstract}
ABSTRAK
Jaringan internet mengalami perkembangan dari tahun ke tahun dan pemanfaatannya juga telah meningkat dan meluas ke berbagai bidang termasuk merambah ke bidan bisnis online.Transaksi jual beli online dapat dilakukan melalui media digital dan tidak memerlukan pertemuan secara langsung antara penjual dan pembeli. Jual beli online ini dinamkana dengan e-commerce dimana sistem ini terus mengalami pertumbuhan.Seiring pertumbuhan tersebut terdapat banyak kecurangan dan penipuan yang terjadi.Banyaknya dampak negatif tersebut tidak menurunkan minat beli seseorang melalui e-commerce.Terdapat dua variabel yang dijadikan pertimbangan munculnya persistensi yaitu keterlibatan dalam jejaring sosial dan kehati-hatian yang dimiliki seseorang akibat rendahnya kepercayaan pasca penipuan.Tujuan penelitian ini adalah untuk mengetahui pengaruh keterlibatan seseorang dalam jejaring sosial dan kehati-hatian terhadap persistensi pada pelanggan online yang pernah mengalami penipuan. Metode analisis menggunakan analisis jalur dengan program AMOS. Hasil dari penelitian ini adalah keterlibatan dalam jejaring sosial berpengaruh langsung maupun tidak langsung terhadap variabel persistensi melalui variabel kehati-hatian.
\end{abstract}

Kata kunci:keterlibatan dalam jejaring sosial, kehati-hatian, persistensi, e-commerce, pelanggan yang memiliki pengalaman tertipu

\section{PENDAHULUAN}

Kondisi masyarakat yang banyak kemudahan dalam berbagai
semakin modern menuntut adanya hal sebagai penunjang aktivitas


sehari-hari. Interaksi berkesinambungan, bekerja sama tanpa dibatasi wilayah, saling berbagi dengan orang lain dari seluruh dunia kapanpun dan dimanapun merupakan gaya hidup masyarakat modern saat ini. Internet merupakan salah satu penunjang untuk dapat berkomunikasi ke berbagai arah tanpa dibatasi ruang dan waktu.Internet digambarkan sebagai sebuah jaringan global seluruh komputer dunia yang besar dan sangat luas berisi berbagai macam informasi serta berfungsi sebagai media komunikasi, riset, transaksi bisnis dan lainnya (Wigan, 2003). Teknologi World Wide Web (WWW), semakin menambah sempurnanya internet sehingga mengalami perkembangan yang luar biasa di mata masyarakat dunia (McLeod dan Schell, 2004).

Penggunaan internet di dunia selalu meningkat dari tahun ke tahun.Internet Worlds Stats mencatat bahwa pengguna internet di seluruh dunia sebesar 0,4\% pada tahun 1995 dan meningkat drastis hingga 60 kali lipat pada tahun 2008. Tidak terkecuali di Indonesia, fenomena meningkatnya penggunaan internet tersebut juga terjadi dari waktu ke waktu. Berdasarkan data Google Analytic yang mengambil sampel dari sebuah situs yang mempunyai nilai kunjungan sekitar 2 jutaperbulan dengan total pengunjung unik mencapai kisaran 900, mencatat bahwa Indonesia menyumbang $97,68 \%$ pengunjung dari total keseluruhan. Data tersebut dapat digunakan sebagai gambaran umum yang mewakili profil pengguna internet di Indonesia.
Kondisi pengguna internet di Indonesia yang semakin meningkat menjadi pemicu menjamurnya $e$ commerce. Pengguna internet mempengaruhi perilaku masyarakat dalam melakukan pembelian barang maupun jasa, yaitu beralihnya pembelian secara konvensional (offline) menjadi secara e-commerce (online). Liao dan Cheung (2001) dalam penelitiannya menemukan bahwa pengguna internet di Singapura yang mengalami peningkatan diiringi pula dengan meningkatnya aktivitas pembelian melalui e-commerce. Kesimpulan dari penelitian tersebut adalah meningkatnya pengguna internet berpengaruh sangat signifikan terhadap ketertarikan seseorang melakukan pembelian melalui $e$ commerce yang lebih dikenal dengan online shop (e-shop).

Data statistik yang dilaporkan oleh Social Media Influence Conference (2010), menyebutkan bahwa terdapat beberapa situs internet terpopuler yang sering digunakan sebagai tempat untuk berbelanja online. Beberapa website yang paling banyak diminati adalah facebook, kaskus, multiply, eBay, tokobagus.com, Groupon, Amazon, RetailMeNot, Bing's Cashback, Like, Overstock, dan Shopzilla.

Berbelanja online menurut sebagian orang dianggap sesuatu yang menyenangkan dan praktis, tetapi bukan berarti belanja online adalah sesuatu yang bebas dari penipuan. Berdasarkan wawancara pada tanggal 18 Oktober 2011 dengan salah satu mahasiswi di Yogyakarta, berusia 23 tahun menyatakan bahwa ia senang berbelanja online tetapi pernah satu kali merasakan sangat kecewa karena 
barang yang dikirimkan tidak sesuai dengan pesanan bahkan barang dalam kondisi rusak dan nomor yang tercantum sebagai contact person pun tidak dapat dihubungi.

Wawancara lain yang sedikit menyangkal bahwa berbelanja online adalah sesuatu hal yang praktis adalah wawancara dengan seorang pemilik toko komputer di Yogyakarta yang dilakukan pada tanggal 21 Oktober 2011 dimana ia aktif dalam bertransaksi melalui sistem $e$ commerce. Ia berpendapat bahwa pembelian yang dilakukan via internet tidak bisa dikatakan praktis karena dalam transaksi pembayarannya pun harus melalui perantara bank dan barang sampai ke tangan pembeli dengan waktu yang cukup lama tergantung juga dari banyak faktor terutama agen pengiriman yang digunakan. Tidak seperti berbelanja di toko offline bahwa pembayaran dan penerimaan dilakukan dalam satu waktu dan satu tempat yang sama sehingga manfaat dari suatu barang yang dibeli bisa langsung dicoba dan dirasakan. Selain itu pembelian melalui toko offline lebih memperkecil kemungkinan terjadinya penipuan.Potensi kejahatan berupa penipuan atau bahkan pembajakan kartu kredit sangat besar kemungkinannya untuk terjadi.Keamanan infrastruktur $e$ commerce sangat diperlukan dalam hal ini.

Keberadaan resiko dalam berbelanja online tidak begitu berpengaruh terhadap eksistensi toko online. Hal ini dibuktikan dengan terus meningkatnya peminat transaksi via e-commerce. Apakah manfaatnya lebih besar dari resikonya?Mencoba menjawab pertanyaan tersebut Corbit, Thanasankit, dan Yi (2003) melakukan penelitian. Hasil dari penelitian adalah bahwa meningkatnya partisipasi konsumen dalam e-commerce salah satunya berkaitan erat dengan kepercayaan. Selain Corbit, dkk (2003), Pavlou dan Gefen (2002) juga melakukan penelitian seputar e-commerce dan hasil penelitian tidak jauh beda dengan penelitian lainnya bahwa kepercayaan menjadi faktor kunci dalam transaksi melalui e-commerce hingga muncul kesetiaan.

Apakah kesetiaan dalam dunia e-commerce ini dapat dianalogikan seperti halnya kesetiaan dalam sebuah hubungan yang memiliki banyak pemakluman ketika dikecewakan pasangannya? Mengadaptasi pernyataan dari Kelly, Skinner, dan Donnelly (1992), bahwa hubungan memerlukan sesuatu yang hangat untuk mencairkan suasana serta didasarkan oleh prinsip-prinsip ketulusan, kepercayaan dan saling mendukung bukan sekedar hubungan transaksional yang semu dan sematamata hanya ingin mengambil keuntungan. Secara pasti, baik kepercayaan dalam dunia e-commerce maupun dalam hubungan kasih sayang, keduanya memerlukan tugas masing-masing dari para pelaku untuk saling melengkapi dan saling mendukung.

Indonesia sebagai salah satu negara yang sedang berkembang ternyata memiliki tingkat pengguna e-commerce yang cukup tinggi dimana didalamnya terdapat tingkat penipuan yang cukup tinggi pula. Berkaitan dengan praktek $e$ commerce yang sedang menjamur 
lengkap dengan sisi negatifnya tersebut, fenomena yang menarik untuk digali adalah bagaimana kepercayaan pelanggan itu selalu ada dan kesetiaan tetap terjaga sementara disisi lain mereka pernah mengalami kekecewaan bahkan tertipu ketika bertransaksi via online.

Banyaknya kasus penipuan
tingkat
menurunkan percayaan pembeli terhadap sistem
e-commerce itu sendiri.Pengalaman
negatif yang dialami oleh pembeli
mengakibatkan meningkatnya sikap
hati-hati dalam melakukan transaksi
selanjutnya. Sikap kehati-hatian
muncul karena adanya keinginan dari
pembeli untuk tetap melakukan
pembelian online namun disisi lain
terdapat rasa ketidakpercayaan yang
diakibatkan oleh pengalaman tertipu
di masa lalu.

\section{METODE PENELITIAN}

Subjek yang digunakan dalam penelitian ini adalah pembeli online melalui e-commerce yang tergabung dalam salah satu komunitas maya dan pernah dikecewakan oleh vendor namun tetap melakukan pembelian online secara berulang.Data yang berhasil dikumpulkan dan dapat diolah lebih lanjut sebanyak 202.Data yang diperoleh melalui sistem online sebanyak 167 responden tetapi hanya 153 yang dapat disertakan dalam analisis.Sebanyak $200 \quad$ skala dibagikan secara offline, dan hanya data dari 49 responden yang dapat dianalisis lebih lanjut.

Metode pengumpulan data yang digunakan dalam penelitian ini adalah dengan menggunakan skala. Pertanyaan dalam skala disusun sendiri oleh peneliti berdasarkan tiga dimensi trust yang diungkapkan oleh Mayer, dkk (1995), involvement in social network dari Valck (2005), dan aspek persistensi dari Schiffman dan Kanuk (2004). Skala dibagikan sebanyak mungkin hingga tercapai jumlah yang diinginkan baik secara online maupun offline dan skala yang diisi secara lengkap oleh responden dijadikan data utama dalam penelitian ini.Hanya data yang benar-benar memenuhi kriteria yang dapat dianalisis lebih lanjut. Pengambilan data secara online menggunakan fasilitas link angket online, email, dan juga melalui mailinglist (kelompok diskusi di internet). Sedangkan pengambilan data secara offline dengan cara memberikan skala cetak kepada responden untuk diisi. Bobot nilai yang digunakan adalah nilai 4=sangat setuju, 3=setuju, 2=tidak setuju, dan $1=$ sangat tidak setuju.

Data yang digunakan berasal dari kuesioner yang telah diisi secara lengkap oleh responden. Selanjutnya data akan diolah menggunakan bantuan program SPSS for windows untuk melihat reliabilitas dan validitas alat ukur, sedangkan program AMOS 20 digunakan untuk melakukan analisis jalur (path analysis). Analisis jalur digunakan dalam penelitian ini karena variabel bebas mempengaruhi variabel tergantung baik secara langsung maupun tidak langsung. Analisis ini juga digunakan untuk melihat tingkat kepentingan dan signifikansi hubungan sebab akibat dalam serangkaian variabel.

\section{HASIL DAN PEMBAHASAN}

Penelitian ini menggunakan tryout terpakai yang artinya data yang diperoleh pada saat tryout diper- 
gunakan kembali pada saat analisis data penelitian.Hal ini disebabkan karena keunikan karakteristik subjek yang masih jarang ditemukan.

\section{Penelitian menggunakan}

sampel berjumlah 202 sehingga estimasi parameter yang digunakan adalah Maximum Likelihood Estimation (MLE). Hasil analisis statistik menunjukkan bahwa nilai chi square adalah sebesar 0,102 dengan nilai probabilitas 0,088 . Semakin kecil nilai chi square yang dihasilkan maka semakin baik model yang diajukan. Dalam uji beda chi square, jika nilai semakin mendekati 0 dengan nilai probabilitas $>0,05$ maka $\mathrm{H}_{0}$ diterima.

Pengujian hipotesis dapat dilakukan dengan menganalisis nilai Critical Ratio (CR) pada hasil pengolahan data kemudian dibandingkan dengan batasan statistik yaitu $\geq 2,0$. Jika hasil olah data menunjukkan nilai yang memenuhi syarat tersebut maka hipotesis penelitian yang diajukan dapat diterima. Hasil pengujian regression weights pada tabel 18 diatas menunjukkan bahwa nilai CR secara keseluruhan berada pada nilai diatas 2,0 sehingga dapat disimpulkan bahwa masing-masing variabel memiliki hubungan. Melalui analisis, kehati-hatian memiliki pengaruh positif secara langsung terhadap persistensi pelanggan online sebesar 0,422 dengan nilai $p$-value yang signifikan sehingga hipotesis pertama yang berbunyi kehati-hatian memiliki pengaruh langsung terhadap persistensi pelanggan online yang memiliki pengalaman dikecewakan oleh vendor dapat diterima. Hasil analisis juga menunjukkan bahwa keterlibatan dalam jejaring sosial memili pengaruh positif secara langsung terhadap persistensi dengan nilai 0,357 dan pengaruh secara tidak langsung terhadap persistensi melalui variabel kehati-hatian sebesar 0,349 sehinga hipotesis kedua yang berbunyi keterlibatan dalam jejaring sosial berpengaruh langsung maupun tidak langsung melalui variabel kehati-hatian terhadap persistensi pelanggan online yang memiliki pengalaman dikecewakan oleh vendor dapat diterima.

Sumbangan efektif secara total yang diberikan oleh variabel keterlibatan dalam jejaring sosial dan variabel kehati-hatian terhadap persistensi adalah sebesar $35,8 \%$ dengan rincian keterlibatan dalam jejaring sosial secara langsung menentukan perubahan terhadap variabel persistensi sebesar 12,7\% dan melalui variabel kehatihatiansebesar 5,3\% sehingga secara total variabel keterlibatan dalam jejaring sosial berpengaruh terhadap persistensi sebesar 18\%, untuk variabel kehati-hatian memiliki pengaruh terhadap variabel persistensi sebesar $17,8 \%$. Sedangkan sisanya yaitu $64,2 \%$ tidak dapat dijelaskan melalui variable-variabel yang digunakan dalam penelitian ini. Sebagian dari angka sisa dapat dijelaskan melalui variabel lain di luar variabel penelitian.

Analisis data dari semua variabel dapat dilihat pada diagram berikut ini: 


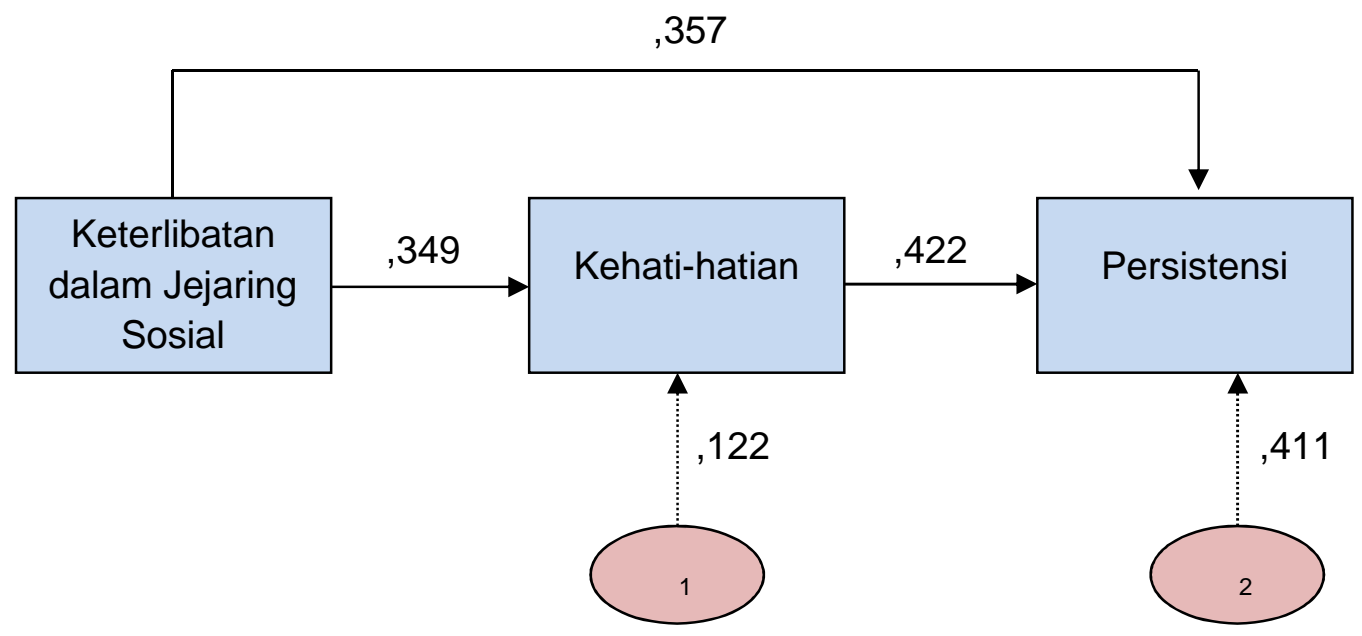

\section{PEMBAHASAN}

\begin{abstract}
Hasil analisis menunjukkan bahwa terdapat hubungan yang
\end{abstract} signifikan antara keterlibatan dalam jejaring sosial, kehati-hatian, dan persistensi. Kehati-hatian terhadap jual beli online melalui jaringan internet (e-commerce) dapat berpengaruh langsung terhadap persistensi dimana kehati-hatian dapat muncul karena dipengaruhi oleh banyak faktor salah satunya adalah dipengaruhi oleh rendahnya kepercayaan terhadap sistem ecommerce yang diakibatkan oleh pengalaman di masa lalu yang pernah ditipu oleh penjual dan keterlibatan seseorang dalam komunitas atau jejaring sosial. Keterlibatan dalam jejaring sosial itu sendiri dapat memunculkan persistensi pelanggan online yang pernah mengalami penipuan karena adanya komunitas akan berpengaruh terhadap munculnya perasaan beresiko yang dapat mengakibatkan ketakutan dan ketidakpercayaan $e$ commerce. Hal ini didukung oleh penelitian Tung et al. (2001) yang menemukan bahwa kepercayaan terhadap e-commerce dipengaruhi oleh keterlibatan anggota yang mendalam dan intensif pada komunitas. Intensitas yang tinggi dalam komunitas akan membentuk jaringan pribadi yang saling mempengaruhi (Rheingold, 1994).

Banyaknya penipuan yang sering terjadi dalam dunia $e$ commerce tidak menurunkan minat beli seseorang pada online shop. Penipuan yang lazim terjadi dalam dunia e-commerce diantaranya adalah tidak dikirimnya barang yang telah dilunasi pembayarannya, keterlambatan pengiriman yang tidak sesuai dengan janji, barang yang dikirimkan tidak sesuai pesanan, dan penjual tidak bertanggung jawab terhadap kerusakan yang terjadi pada barang. Melalui penelitian ini ditemukan jawaban bahwa penipuan tidak berpengaruh signifikan terhadap intensitas beli seseorang melalui sistem e-commerce. Hal ini ditunjukkan dengan pernyataan sebjek yang sebagian besar 
mengatakan bahwa setelah tertipu dampak yang paling nyata adalah berpindah tempat belanja di online shop yang lain dengan harapan tidak akan tertipu lagi seperti pengalaman di masa lalunya.

Selain melalui kehati-hatian, persistensi terhadap e-commerce terbentuk karena adanya pengaruh komunitas sebagai faktor eksternal. Banyaknya responden yang berada pada usia dibawah 25 tahun menunjukkan bahwa sebagian besar responden berada pada usia remaja, sebagaimana dikatakan oleh Santrock (2003) bahwa seseorang berada pada masa remaja ketika berusia 12-23. Pada masa remaja ini terdapat kebutuhan untuk dapat diterima oleh lingkungan. Setiap orang yang memasuki usia remaja akan dihadapkan pada permasalahan penerimaan teman sebaya yang meliputi pembentukan sikap, tingkah laku, dan perilaku sosial remaja yang banyak ditentukan oleh pengaruh lingkungan ataupun teman sebaya. Dewasa ini komunitas merupakan salah satu tempat yang banyak digunakan remaja untuk saling berbagi. Jejaring sosial di dunia maya (online) merupakan tempat paling strategis untuk berbagi pengalaman dengan orang lain yang memiliki hobi yang sama dan pada tingkatan usia yang relatif sama pula. Pada jejaring sosial ini penggunaannya tanpa dibatasi ruang dan waktu sehingga dapat terjadi kapan saja dan dimana saja yang mengakibatkan komunikasi antar anggota dapat terjadi lebih intensif (Romm, dkk, 1997).Keterlibatan mendalam yang memiliki intensitas tinggi dalam suatu komunitas dapat mempengaruhi sikap dan pandangan seseorang terhadap suatu hal (Mitchell, 1969). Konsumen yang bergabung dalam suatu komunitas dan memiliki waktu aktif yang cukup lama cenderung akan bertingkah laku dan memiliki pemilikiran yang sama dengan komunitasnya (Baron \& Byrne, 2005). Data penelitian juga menyebutkan bahwa komunitas akan meningkatkan kepercayaan diri seseorang dalam bertindak dan seseorang memiliki anggapan bahwa pendapat teman komunitas merupakan sesuatu yang penting sehingga orang tersebut akan selaras dengan kelompoknya karena memiliki penilaian bahwa kelompoknya adalah benar.

Hubungan antar pelanggan online yang terjalin kuat akan sangat menentukan tingkat keputusan seseorang untuk kembali menggunakan e-commerce sebagai fasilitas berbelanja atau sebaliknya akan beralih pada pasar konvensional. Keputusan tersebut dapat dipengaruhi oleh banyak faktor salah satunya adalah lingkungan atau kelompok tempat seseorang menghabiskan waktunya secata intens (Engel, 1990). Hubungan antar pelanggan ini tertuang pada jaringan sosial online (Chou \& Chou, 2009). Jaringan sosial melibatkan beberapa individu yang memiliki kepentingan yang sama dan saling bertukar informasi (Ahn, 2007). Haythornthwaite (2005) menjelaskan bahwa dalam jaringan sosial atribut individu kurang dipentingkan tetapi lebih fokus pada hubungan antar individu dalam kelompok. Suatu keterlibatan yang terbentuk secara total dalam kelompok akan mempengaruhi tingkah laku yang dimunculkan oleh individu yang 
terlibat secara langsung dalam kelompok tersebut (Mitchell, 1969). Individu yang memiliki keterlibatan erat dalam komunitas virtual akan memiliki ketersediaan untuk mematuhi peraturan atau norma yang dianut oleh kelompok termasuk cara pandang kelompok terhadap sistem e-commerce sebagai salah satu fasilitas transaksi jual beli barang secara online (Burnkrant \& Cousineau, 1975). Beberapa penjabaran mengenai hubungan dalam kelompok ini memberikan gambaran betapa lemahnya seseorang terhadap pengaruh lingkungan. Lingkungan memiliki pengaruh lebih besar jika dibanding dengan pengalaman pribadi yang pernah dialami sehingga seseorang akan berperilaku sesuai dengan harapan kelompok (Shepard, 1974).

Selain komunitas sebagai pendorong eksternal yang menjadi alasan mengapa seseorang tetap membeli barang melalui sistem $e$ commerce meskipun pernah mengalami penipuan, terdapat pula faktor lain sebagai pendorong yang merupakan indikasi munculnya kehati-hatian dalam diri seseorang yang diakibatkan oleh rendahnya tingkat kepercayaan seseorang pasca dikecewakan maupun ditipu oleh online shop. Salah satu hal sebagai perwujudan sikap kehati-hatian adalah pembeli meningkatkan kewaspadaan diri dengan lebih selektif dalam memilih online shop.Hal tersebut menunjukkan bahwa kepercayaan dapat dibangun sendiri oleh individu dengan meningkatkan kehati-hatian, bukan berdasarkan bagaimana penjual memperbaiki kesalahan agar pembeli tidak merasa ditipu. Hal ini berbanding terbalik dengan penelitian Utz, dkk (2009) yang melalui sebuah penelitian menyimpulkan bahwa reaksi yang dimunculkan oleh penjual dalam menanggapi ketidakpuasan pelanggan dapat memperbaiki kepercayaan secara signifikan.

Data yang di dapat melalui penelitian ini menyebutkan bahwa pembeli hanya memperhatikan bagus atau tidaknya barang yang dijual dengan cara memantau perkembangan barang yang dijual melalui internet. Ketika pembeli merasa barang tersebut bagus dan menarik maka mereka akan membelinya. Sebagian besar responden menyatakan bahwa mereka tidak memperhatikan ada tidaknya komentar negatif dari pembeli lain karena pada dasarnya jarang sekali penjual yang mau meminta maaf dan menukar barang ketika terjadi komplain yang disampaikan oleh pembeli sehingga pembeli meningkatkan kewaspadaan diri untuk memperkesil kemungkinan tertipu kembali oleh online shop.

Daya tarik online shop yang terkemas dalam e-commerce yang menawarkan berbagai bentuk kemudahan menjadi alasan tersendiri munculnya persistensi dalam penikmat dunia e-commerce. Selain terbawa arus komunitas, adanya pengaruh gaya hidup dan kecanggihan dalam menawarkan produk secara visual merupakan faktor penting pembentuk persistensi seseorang terhadap pembelian online. Gaya hidup anak muda jaman sekarang yang tidak mau repot dan senang dianggap keren adalah salah satu modal yang dimiliki para pelaku 
bisnis online untuk semakin mengembangkan usaha dalam dunia e-commerce. Menjamurnya pelaku bisnis online saat ini dapat dikatakan sebagai salah satu dampak globalisasi sehingga penjualan dan pembelian dapat dilakukan kapanpun dan dimanapun baik pembelian untuk barang-barang dalam negeri maupun pembelian lintas negara. Hal ini turut mencerminkan bahwa saat ini terjadi peningkatan kualitas hidup dan perekonomian sehingga perdagangan tanpa dibatasi ruang dan waktu dapat terjadi tanpa memperhatikan materi sebagai bahan pertimbangan ketika akan melakukan pembelian.

\section{KESIMPULAN DAN SARAN}

Kesimpulan

Berbelanja via e-commerce masih menjadi pilihan bagi para pelanggan yang pernah mengalami kekecewaan. Berdasarkan hasil analisis menunjukkan bahwa terdapat hubungan antara keterlibatan dalam jejaring sosial, kehati-hatian, dan persistensi. Kehati-hatian terhadap jual beli online melalui jaringan internet (e-commerce) yang muncul diakibatkan oleh rendahnya tingkat kepercayaan pelanggan terhadap sistem dapat berpengaruh langsung terhadap persistensi.

Persistensi pada pelanggan yang pernah mengalami penipuan dapat terbentuk karena gaya hidup saat ini yang menginginkan kemudahan dalam memenuhi kebutuhan konsumsinya. Internet yang dapat diakses tanpa dibatasi ruang dan waktu merupakan salah satu faktor yang dianggap mampu untuk memenuhi kemudahan yang diinginkan individu saat ini. Bergeraknya kebiasaan budaya tradisional ke arah digital juga membawa perubahan pada gaya komunikasi. Tingginya intensitas berinteraksi melalui media internet memunculkan berbagai komunitas lengkap dengan karakteristik masingmasing yang dapat mempengaruhi pola hidup dan perilaku seseorang termasuk kesenangan dan pilihan dalam melakukan belanja.

Kehati-hatian turut berperan
dalam membentuk persistensi
seseorang terhadap e-commerce sebagai wujud kewaspadaan terhadap penipuan.Kepercayaan merupakan modal utama agar transaksi dalam jual beli online dapat dilakukan.Hal ini disebabkan karena antara penjual dan pembeli tidak bertemu secara langsung dan hanya bermodalkan hubungan via online tawar menawar barang dilakukan. Bagaimana kepercayaan kembali terbentuk pasca dikecewakan karena sebuah penipuan tidak hanya berasal dari usaha penjual memperbaiki kesalahan tetapi dari sisi lingkungan dimana subjek sering berinteraksi. Kemauan subjek bertransaksi kembali via e-commerce dengan penuh kehati-hatian merupakan konsekuensi terhadap kekecewaan yang pernah dialami di masa lalu.

Saran

Total sumbangan efektif yang ditemukan dalam penelitian ini melalui variabel keterlibatan dalam jejaring sosial dan kehati-hatian dalam mempengaruhi persistensi adalah sebesar $35,8 \%$ sehingga terdapat $64,2 \%$ yang belum mampu dijelaskan oleh variabel penelitian ini. Besarnya angka variabel residu 
memungkinkan untuk dikembangkannya model penelitian yang lebih kompleks. Peneliti selanjutnya dapat membandingkan antara data responden yang pernah mengalami penipuan dan belum pernah mengalami penipuan sehingga dapat dilihat bagaimana perbedaan hasilnya jika variabel yang sama diterapkan dalam dua kelompok subjek yang berbeda. Hasil penelitian diharapkan mampu menjawab pertanyaan apakah variabel kehatihatian juga dimiliki oleh pelanggan yang belum pernah tertipu ketika mereka bertransaksi melalui $e$ commerce.

\section{DAFTAR PUSTAKA}

Ahn, Y-Y.(2007). Analysis of topological characteristics of huge online social networking services. Session: Semantic Web and web 2.0, 835-844.

Assael, H. (1998). Consumer Behavior and Marketing Action 6th.ed. New York: International Thomson Publishing.

Azwar, S. (2006).Penyusunan Skala Psikologi. Yogyakarta: Pustaka pelajar.

Ba, S., \& Pavlou, P. A. (2004).Evidence of the effect of trust building technology in electronic markets: price premiums and buyer behavior. MIS Quarterly, 26(3), 243-268.
Baron, R. A., \& Byrne, D. (2005).Psikologi Sosial Jilid 2 10th.ed. Jakarta: Erlangga

Blackston, M. (1992). A brand with an attitude: a suitable case for the treatment. Journal of the market research society, 34(3), 231-241.

Chou, A. Y., \& Chou, D. (2009). Information system characteristics and social network software adoption. Proceedings of the SWDSI Conference, 335-343.

Ding, J. (1999). E-commerce: law and practice. Journal of Electronic Commerce, 13(4), 99-122

Gaertner, N. \& Smith, M. (2001). Ecommerce in a web-based environment: auditing relative advantages in the australian health sector. Managerial Auditing Journal, 16(6), 347365.

Haythornthwaite, C. (2005). Social networks and internet connectivity effects.Information, Communication \& Society, 8(2), 125-147.

Jun, M., Yang, Z., \& Kim, D. (2003). Customers' perceptions of online retailing service quality and their satisfaction. International Journal of Quality and Reliability Management, 21(8), 817-840 
Mayer, R.C., Davis, J. H., \& Schoorman, F. D. (1995).An integratif model of organizational trust.Academy of Management Review, 30(3), 709-734.

Mitchell, J. C. (1969). Social Networks in Urban Situations. Manchester: Manchester University Press.

Ratchford, B. T., \& Srinivasan, N. (1991).An empirical test of a model of external search for automobiles.Journal of Consumer Research, 18(9), 233-242.

Rheingold, H. (1993). The virtual community.Journal of Strategic Information Systems, 7(11), 271-295.

Santrock, J. W. (2003). Adolescence. Jakarta: Erlangga.
Schiffman, L. G., \& Kanuk, L. L. (2004).Consumer Behavior 8th.ed. New Jersey: Prentice Hall.

Sevdik, A. B. \& Akman, V. (2002). Internet in the lives of turkish women. First Monday: PeerReviewed Journal on The Internet, 7(3), 80-95

Shepard, J. M. (1974). Alienation and social referents.Sociology and Social Research, 9(1), 5560.

Tung, L. L. (2001). An empirical investigation of virtual communities and trust.Proceedings of TwentySecond International Conference on Information Systems (pp. 307- 319).

Valck, K. D. (2005). Virtual communities of consumption: networks of consumer knowledge and companionship.

European Journal of Information Systems, 15(6), 542-555 